Apidologie, 1980, 11 (4), 341-350.

\title{
NECTAR AND POLLEN RESOURCES FOR STINGLESS BEES (MELIPONINAE, HYMENOPTERA) IN SURINAM (SOUTH AMERICA)
}

\author{
M. S. ENGEL ${ }^{1}$ and F. DINGEMANS-BAKELS ${ }^{2}$
}

\section{SUMMARY}

By means of several methods information on the floral resources of the stingless bees of Surinam has been obtained. This study reports on about 100 plant species visited by 37 species of stingless bees. It appears that there is a considerable overlap in the food plants of the different bee species. Some small flowers or flowers with a long and narrow corolla seem to be visited exclusively by small bees : Asystasia species by Trigona pallens and Orthosiphon grandiflorus by Plebeia minima. Solanum species are visited exclusively by the bees (Melipona spec., $T$. fulviventris guianae) that are able to loosen the pollen by vibrating.

For the first time it is reported that stingless bees (M. favosa, M. compressipes, T. hyalinata branneri) collect pollen from Polygonacaea ( $P$. acuminatum, Triplaris surinamensis, Cocoloba lucidula).

Most important food plants for M. favosa are : Avicennia germinans, Aciotes dichotoma, Syzygium cumini, Polyganum acuminatum and Solanum species.

\section{INTRODUCTION}

Stingless bees form a group of pantropical social bees. Not much has been published about their occurrence in Surinam. SCHWÁRz (1948) mentions a number of species collected by the Cornell University Expedition there. A more recent publication on Meliponinae in Surinam is by REYNE in 1962. His paper is a mere summation of all stingless bees occurring in Surinam, with notes on the specimens (collector, location of sampling, and other observations). In most cases REYNE (1962)

1. Laboratory of Comparative Physiology, Jan van Galenstraat 40 , Utrecht, and Laboratory of Palaeobotany and Palynology, Heidelberglaan 2, Utrecht, the Netherlands.

2. Nekummerweg 25, Maastricht, the Netherlands. 
observed bees chewing* on leaves or fruits. Trigona fulviventris guianae was seen on bananaflowers (Musa), but no further reference to either chewing or foraging was given. His list gives a total of 28 Meliponin bees. Since then new material has been added, now mainly in the collection of the Rijksmuseum voor Natuurlijke Historie at Leiden. This material is being studied and results will be published in due time (Dingemans-Bakels, in prep.). About twice as many species are known now. The observations of REYNE (1962) are to our knowledge the only data on food sources for stingless bees in Surinam.

The first to gain knowledge on floral resources for stingless bees in tropical America was Ducke $(1901,1902)$. He observed flower visits in Parā (North-east Brasil). After these publications very little appeared to enhance our knowledge in this field except for incidental information in taxonomic studies and in studies on pollination biology. However the interest in food sources and related problems (e.g. foraging behaviour, recruitment) has been growing recently (LINDAUER and KERR, 1958; Johnson and HubBell, 1974; Absy and KerR, 1977; HubBell and JoHnson, 1978; Roubik, 1979 and IwAma and Melhem, 1979).

Object of this study is to procure data on floral resources for stingless bees in Surinam. The knowledge on floral ecology may also benefit from this study by giving information on potential native pollinators.

It is fortunate that the flora of Surinam has been studied in great detail. Pulle started a comprehensive study on it which has been continued by many other botanists mainly from the Botanical Department of Utrecht University. Apart from native plants, the flora of Surinam consists of a large number of introduced plants. Immigrants from India and Java (Indonesia) had brought with them large numbers of garden and edible plants. (All plants mentioned by REYNE (1962), apart from bananas, are introduced plants.)

Data were obtained in different ways. Accompanying notes of a museum collection of Meliponin bees provided information on which plants the bees had been caught. Pollen and honey samples collected by ENGEL during a stay of two months (August-September, 1978) in Surinam were microscopically analyzed. So were the samples that were taken from the stingless bee colonies originating from Surinam and kept at the Laboratory of Comparative Physiology in Utrecht. During this stay field observations were also made.

\section{MATERIALS AND METHODS}

Most bees of the museum collection were caught in the savannah area of Surinam. These bees and those caught during field work were all identified by Dingemans-BAKELs. Field work was done mainly in

* Meliponins chewing on plants: Trigona amalthea, $T$. dallatorreana, T. kaieteurensis and Trigona spec. on Citrus leaves; T. amalthea on Vigna sinensis ( $=V$. unguiculata $(\mathrm{L}$.$) Walp., Papillionaceae), Colocasia antiquorum (=C$. esculenta (L.) Schott., Araceae), Artocarpus incissus (= A. communis J. R. and G. FORTSTER, Moraceae) and young bananas (Musa spec., Musaceae). 
the coastal area, the immediate surroundings of the capital Paramaribo, and south of Paramaribo in the polders. The plants on which bees were found were dried and afterwards identified. These identifications were later verified at the Land's Herbarium in Paramaribo.

Getting samples of honey and pollen from tended colonies of Meliponins proved to be difficult. Only two beekeepers who kept stingless bees were known, both were living in the coastal area. Species kept were Melipona favosa and $M$. compressipes. At the Laboratory of Comparative Physiology at Utrecht, some $M$. favosa colonies originating from Surinam were kept for behavioural studies. Directly upon arrival in the Netherlands samples were taken from these too.

The total number of samples thus obtained is 27 . Of these 23 samples have been taken from pollen storage pots (21 from $M$. favosa and 2 from $M$. compressipes), 3 pollen baskets (1 M.favosa and $2 M$. compressipes) and unfortunately only one honey sample( $M$. favosa).

The material was prepared by the standard acetolysis method as given by REITSMA (1969). Besides evident advantages (material being clean and clear, durability of the slides) this method has the disadvantage in that pollen of several families like the Musaceae and Lauraceae is destroyed during this process.

As no palynological literature dealing with plant taxa from Surinam exists a reference slide collection had to be made. The initial choice of plants for this collection was based on data given by DUCKE (1901, 1902), ASBY and Kerr (1977) and our own information. Plants chosen for the reference slide collection came from the Utrecht Herbarium, and when available plants originating from Surinam were used. Afterwards the pollen found in the samples was compared with that of the reference slide collection.

Both ways of obtaining data have their restrictions. First, bees may be caught on plants which do not contribute to their diet (vide REYNE, 1962). As collecting bees in trees is rather difficult trees and epiphytes will be underrepresented. Secondly, no traces of flower visits will be found if pollen is detroyed during acetolysis. The same applies in the case of nectar robbing, a trait not rare for Trigona (BARRows, 1976). And thirdly, the number of pollen types that can be identified depends on the reference slide collection being complete.

\section{RESULTS}

All data, comprising those from the museum collection, microscopical analysis and field observations, are shown in Table $\mathrm{I} a, \mathrm{I} b$ and $\mathrm{I} c$. Table I $a$ contains the data for the genus Melipona, I $b$ for true Trigona, and I $c$ for the other genera.

In some cases the vernacular names of plants on which the bees were caught have been given. These names often indicate a whole genus or even a whole family. This is the case with "tingimoni ": Burseraceae and "purslane ": Portulacaceae. "Koenami, another vernacular name given, is a fish poison and may be derived from very different plants. The following plants are used in Surinam as "koenami " : Clibadium spec. (Compositae) and Tephrosia toxicara (Papillionaceae). Meliponins caught on "koenami" are : Melipona seminigra pseudocentris, $M$. rufiventris paraensis, $M$. scutellaris lateralis and Trigona cilipes. 
TABL. Ia. - Floral resources for the genus Melipona.

Table Ia. Floral resources for the genus Melipona. $\square=$ data from notes of the museum collection, $\square=$ data by microscopical analysis, $\Delta=$ data from field observations. Full scientific names are: $M$. captiosa Moure, M. compressipes (F.), M. favosa (F.), M. flavipennis Smith, M. illustris Schwarz, M. interrupta interrupta (Latr.), M. rufiventris paraensis (Ducke), M. scutellaris latitarsis (Erichson) and M. seminigra pseudocentris (Ck11.).

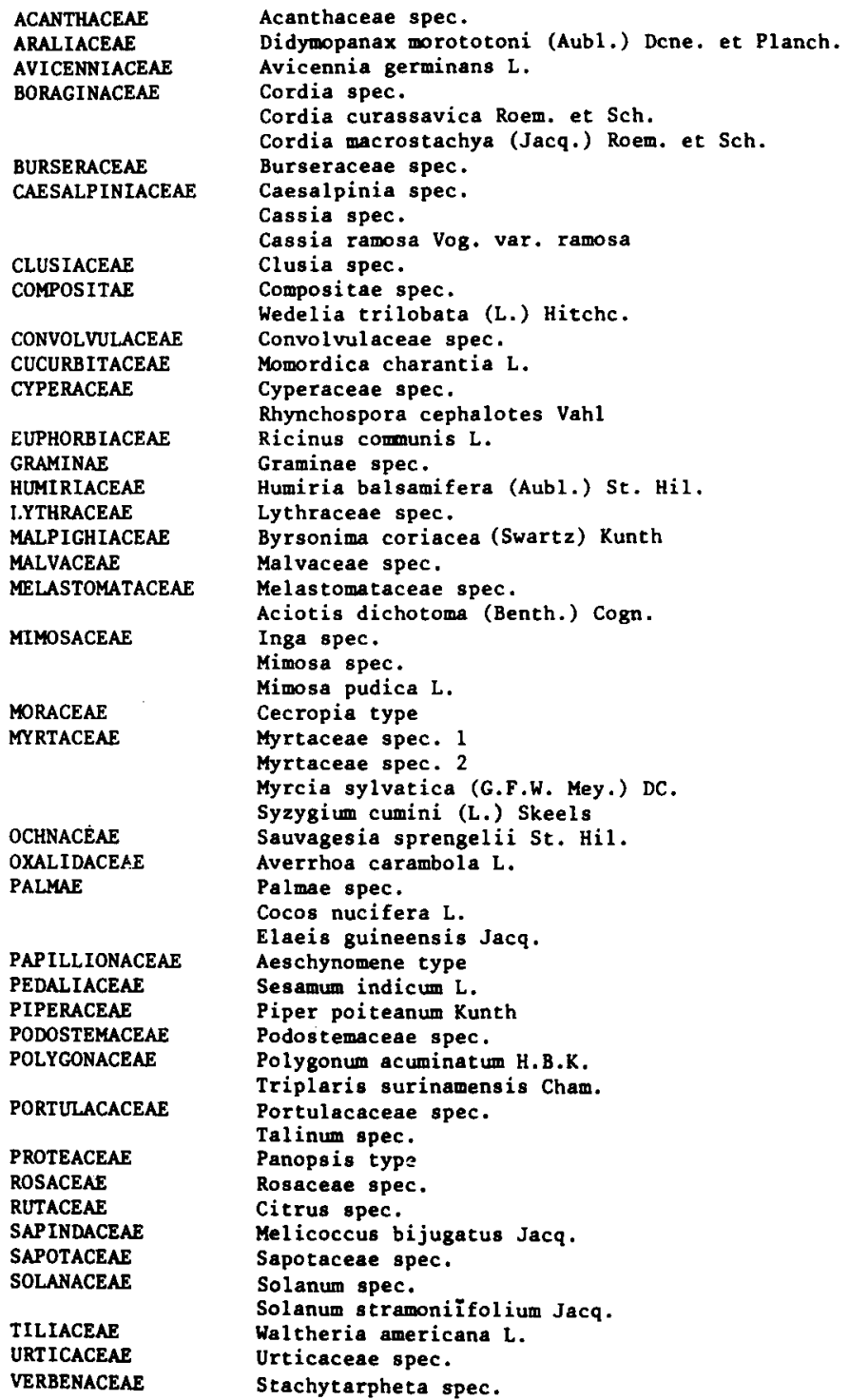

a

- 
TABL. Ib. - Floral resources for true Trigona.

Table Ib. Floral resources for true Trigona, $\square$ and $\Delta$ as in Table Ia. Full scientific names are: T. cilipes (F.), T. clavipes (F,), T. dallatorreana Friese, T. dorsal is beebei Schwarz, T. flavicornis (F.), T. fulviventris guianae Ck11., T. fuscipennis Friese, T. ghilianii (Spinola), T. handlirschi Friese, T. hyalinata branneri Ck11., T. jaty Smith, T. kaieteurens is Schwarz, T. lurida Smith, T. pallens (F.), T. recursa Smith, $T$. varia (Lep.) and $T$. williana Friese.

\begin{tabular}{|c|c|}
\hline ACANTHACEAE & Asystasia spec. \\
\hline ANNONACEAE & Annona spec. \\
\hline BEGONTACEAE & Begonia spec. \\
\hline BORAGINACEAE & $\begin{array}{l}\text { Cordia spec. } \\
\text { Cordia macrostachya (Jacq.) Roem. et Sch, }\end{array}$ \\
\hline CAE SALPINIACEAE & $\begin{array}{l}\text { Cassia spec. } \\
\text { Cassia multijuga L.C. Rich. } \\
\text { Cassia ramosa Vog. var. ramosa }\end{array}$ \\
\hline CLUSIACEAE & Clusia spec. \\
\hline COMPOSITAE & $\begin{array}{l}\text { Clibadium surinamense L. } \\
\text { Vernonia remotiflora L.C. Rich. } \\
\text { Wulffia baccata (L.f.) Kuntze }\end{array}$ \\
\hline CONVOLVULACEAE & Convolvulus spec. \\
\hline CUCURBITACEAE & Momordica charantia L. \\
\hline CYPERACEAE & $\begin{array}{l}\text { Cyperaceae spec. } \\
\text { Bulbostylis spec. }\end{array}$ \\
\hline GRAMTNAE & Zea mays $L$. \\
\hline HUMI R LACEAE & Humiria balsamifera (Aubl.) St. Hil. \\
\hline LABIATAE & $\begin{array}{l}\text { Hypt is spec. } \\
\text { Hypt is atrorubens Poit. }\end{array}$ \\
\hline LORANTHACEAE & Phoradendron piperoides (H.B.K.) Trelease \\
\hline MALP IGHIACEAE & Malpighiaceae spec. \\
\hline MALVACEAE & Hibiscus spec. \\
\hline MELASTOMATACEAE & Melastomataceae spec. \\
\hline MIMOSACEAE & $\begin{array}{l}\text { Calliandra surinamensis Bth. } \\
\text { Neptunia plena (L.) Bth. }\end{array}$ \\
\hline MUSACEAE & $\begin{array}{l}\text { Heliconia spec. } \\
\text { Musa spec. }\end{array}$ \\
\hline MYRTACEAE & Myrcia sylvatica (G.F.W. Mey.) DC. \\
\hline ONAGRACEAE & Ludwigia leptocarpa (Nutt.) Hara \\
\hline PALMAE & $\begin{array}{l}\text { Cocos nucifera L. } \\
\text { Hyospathe elegans Mart. } \\
\text { Orbignya spec. }\end{array}$ \\
\hline PASSIFLORACEAE & Passiflora spec. \\
\hline PAPILLIONACEAE & Phaseolus lunatus $\mathrm{L}$. \\
\hline PEDALIACEAE & $\begin{array}{l}\text { Sesamum spec. } \\
\text { Sesamum indicum L. }\end{array}$ \\
\hline POLYGONACEAE & Coccoloba lucidula Benth. \\
\hline RUBIACEAE & $\begin{array}{l}\text { Borreria capitata (R. et P.) DC. } \\
\text { Borreria latifolia (Aubl.) K. Sch. } \\
\text { Borreria ocimoides (Burm.) DC. } \\
\text { Retiniphyllum schomburgkii (Bth.) Müll. Arg. }\end{array}$ \\
\hline RUTACEAE & Citrus spec. \\
\hline SAPINDACEAE & Melicoccus bijugatus Jacq. \\
\hline SOLANACEAE & $\begin{array}{l}\text { Solanum spec. } \\
\text { Solanum melongena } L \text {. }\end{array}$ \\
\hline STERCULIACEAE & Melochia ulmifolia Benth. \\
\hline $\begin{array}{l}\text { THEACEAE } \\
\text { VERBENACEAE }\end{array}$ & $\begin{array}{l}\text { Ternstroemia punctata (Aubl.) Sw. } \\
\text { Holmskioldia sanguinea Retz. }\end{array}$ \\
\hline VITACEAE & Cissus spec. \\
\hline
\end{tabular}

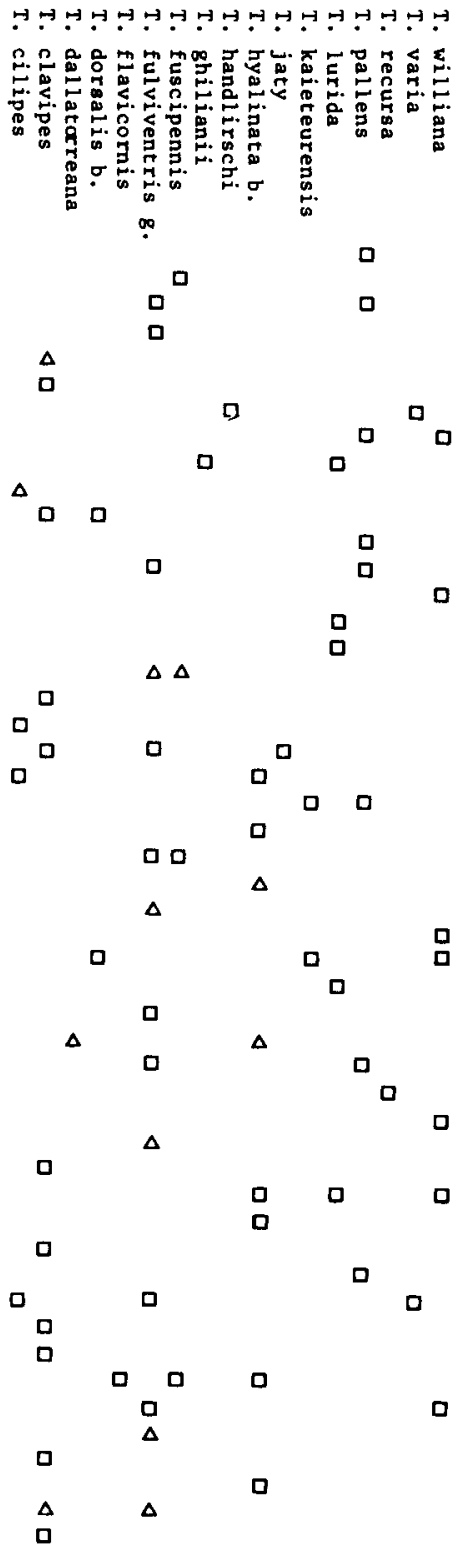

The reference slide collection is still far from complete as nothing was known on the floral resources for stingless bees in Surinam. This is why a number of pollen types could only be identified to family or genus level. Nevertheless out of 43 pollen types only 7 could not be identified.

Plant taxa that are visited by bees of more than one genus are the Caesalpiniaceae, Clusiaceae, Melastomataceae, Palmae, Sesamum and Solanum. These taxa are 
TABL. Ic. - Floral resources for the other genera.

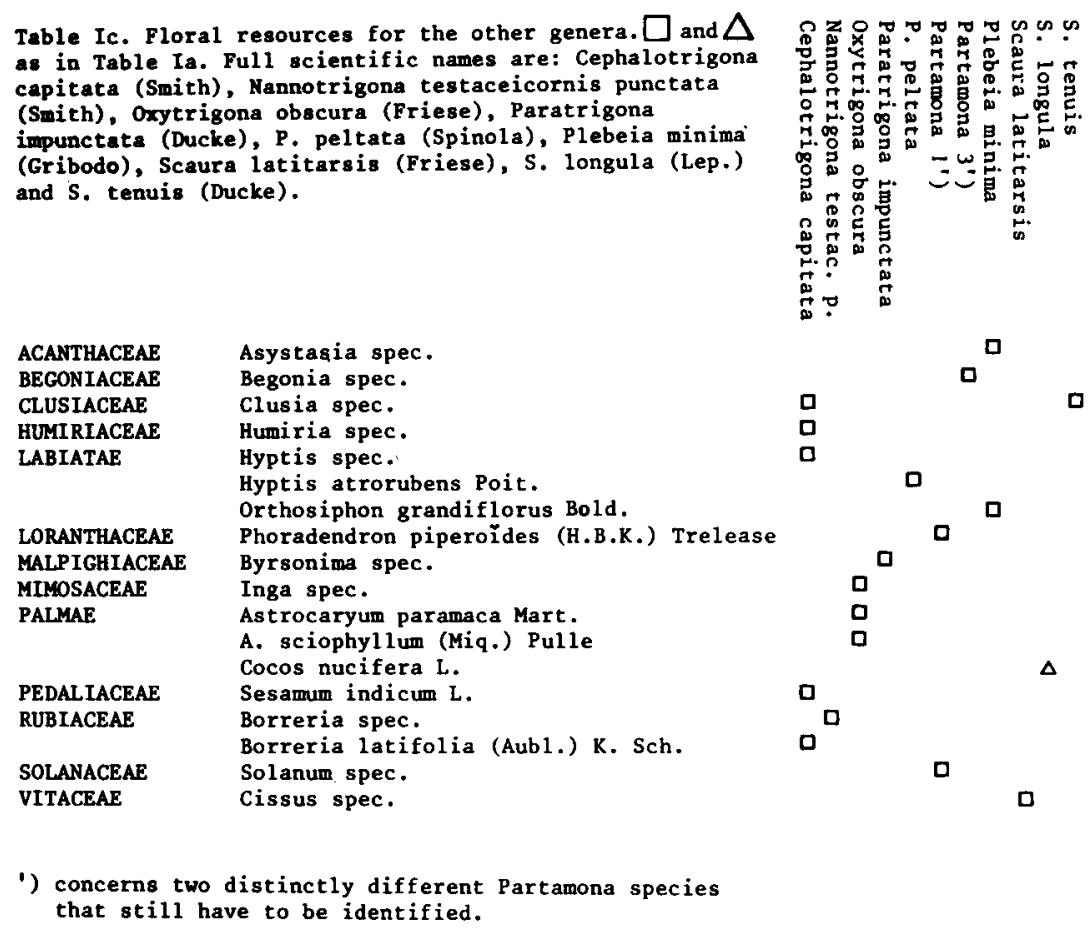

probably important floral resources for stingless bees in general. There are too few data to split them on (bee) species level, but a comparison between the largest two genera, Melipona and Trigona (Tables I $a$ and $\mathrm{I} b$ ) has been made. Data from the pollen analysis were exclused from this comparison, as samples were taken in different vegetation types (savannah and coastal area). On the following taxa more than one Trigona species was caught, but never a Melipona: Begoniaceae, Hyptis, Loranthaceae, Musaceae and Rubiaceae. On Ludwigia leptocarpa (Onagraceae), Ricinus communis (Euphorbiaceae) and Cissus spec. (Vitaceae) only one Trigona species was caught and no Melipona. Being incidental observations, these data have to be regarded with reserve. On the other hand the Podostemaceae, Portulacaceae (visited by resp. 3 and 2 Melipona species), the Burseraceae, Sauvagesia sprengelii (Ochnaceae) and Piperaceae (all visited by one Melipona) are absent on the list of the Trigona (Table $\mathrm{I} b$ ).

The results of the microscopical analysis of the pollen samples of Melipona favosa (23 samples) are shown quantitavely in Table II. Frequency classes of the pollen types are large : incidental pollen (less than 5\%), frequent pollen (5-30\%) and abundant pollen (over $30 \%$ ). This was done as the material in the pollen pots is not homogenized and only small samples could be taken. Most important pollen yielders 
for M.favosa are : Avicennia germinans, Aciotis dichotoma, Myrtaceae spec., Polygonum acuminatum and Solanum spec.

TABL. II. - Number of samples of Melipona favosa (F.)

containing pollen of plant species within each frequency ctass.

Table II.

Number of samples of Melipona favosa (F.) containing pollen of plant species within each frequency class. Frequency classes: incidental pollen (less than $5 \%$ ), frequent pollen $(5-30 z)$ and abundant pollen (over $30 \%$ ). $N=23$.

$\begin{array}{ll}\text { ARALIACEAE } & \text { Didymopanax morototoni (Aubl.) Dcne. et Planch. } \\ \text { AVICENNIACEAE } & \text { Avicennia germinans L. } \\ \text { BORAGINACEAE } & \text { Cordia macrostachya (Jacq.) Roem. et Sch. } \\ \text { CAESALPINIACEAE } & \text { Caesalpinia spec. } \\ \text { COMPOSITAE } & \text { Compositae spec. } \\ \text { CUCURBIATACEAE } & \text { Momordica charantia } \\ \text { CYPERACEAE } & \text { Cyperaceae spec. } \\ \text { GRAMINAE } & \text { Graminae spec. } \\ \text { HUMIRIACEAE } & \text { Humiria balsamifera (Aub1.) St. Hil. } \\ \text { LYTHRACEAE } & \text { Lythraceae spec. } \\ \text { MALPIGHIACEAE } & \text { Byrsonima coriacea (Swartz) Kunth } \\ \text { MALVACEAE } & \text { Malvaceae spec. } \\ \text { MELASTOMATACEAE } & \text { Melastomataceae spec. } \\ & \text { Aciotis dichotoma (Benth.) Cogn. } \\ \text { MIMOSACEAE } & \text { Inga spec. } \\ & \text { Mimosa spec. } \\ \text { MORACEAE } & \text { Mimosa pudica L. } \\ \text { MYRTACEAE } & \text { Cecropia type } \\ \text { PALMAE } & \text { Myrtaceae spec. } \\ \text { PAPILLIONACEAE } & \text { Syzygium cumini (L.) Skeels } \\ \text { POLYGONACEAE } & \text { Palmae spec. } \\ \text { PROTEACEAE } & \text { Polygonum acuminatum } \\ \text { SAPOTACEAE } & \text { Panopsis type } \\ \text { SOLANACEAE } & \text { Sapotaceae spec. } \\ \text { URTICACEAE } & \text { Solanum spec. } \\ \text { Urticaceae spec. }\end{array}$

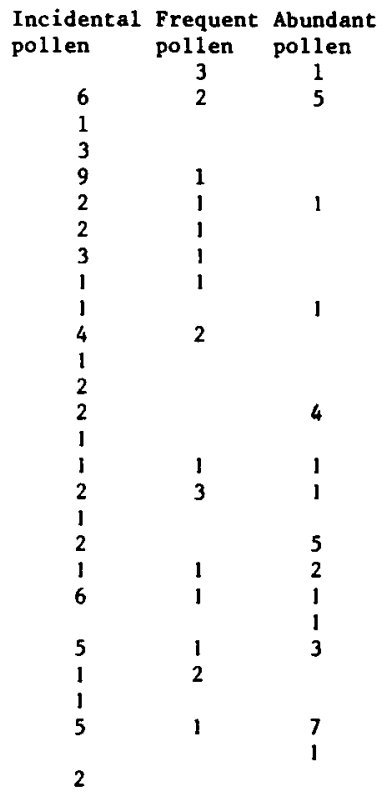

\section{DISCUSSION}

Meliponinae are social bees that have to maintain a broodnest the whole year round. They are generalists in their food choice as they cannot afford to be oligolectic. However some specialisation must occur as more species can coexist in the same habitat albeit that to some extent they have an overlap in their floral resources. How these specialisations are induced and manifested is hard to say. Preference for a flower syndrome, time of forage activity, interspecific aggression and recruitment techniques will all play a role. As we have so little data for each beespecies on its floral resources nothing can be said on their preference for a certain flower syndrome. Our data do not contain information on the other aspects. Size of the visiting bee will also play a role : nectar and/or pollen of very small flowers, or flowers with a long and narrow corolla will be inaccessible for larger bees if they try to obtain it in a legitimate way. The body sizes of the bees range between $2 \mathrm{~mm}$ (Plebeia minima) and $13.5 \mathrm{~mm}$ (Melipona flavipennis). The bees were divided in two size classes, and the data were considered again. Most data concern the larger bees: 
Melipona, most Trigona and Cephalotrigona capitata. The smallest bees are Plebeia minima, the Paratrigona species and Trigona jaty. Only on some plants small, but no large bees were caught. These are Asystasia spec. (Acanthaceae), which has a long and narrow corolla, and Orthosiphon grandiflorus, a Labiatae. On the other hand large bees were caught on some small flowers like Hyptis (Labiatae) and Borreria (Rubiaceae). On some flowers large numbers of bees belonging to the larger size class were caught. Even considering the fact that more data are available on the larger than on smaller bees the absence of the latter is striking. The flowers in question are : Solanum, Melicoccus bijugatus and Sesamum indicum. Solanum has anthers with terminal pores and may rely solely on "buzz pollination " (like some Caesalpiniaceae; BUCHMANN, 1974; ANZENBERgER, 1977). By hanging over to pores and vibrating the pollen is loosened and shoots out of the pore onto the body of the bee. Slighter bees may not succeed in loosening the pollen in this way. No suggestion can be made for the absence of smaller bees on Melicoccus bijugatus and Sesamum indicum.

In Table I $a$ can be seen that data by microscopical analysis (black squares) rather add new plant species to the list than confirm the data found on the accompanying notes of the museum collection (open squares). The main reason for this is the fact that sampling was done in different vegetation types: the savannah and the coastal area.

The articles of DuCKe $(1901,1902)$ are on flower visits of Meliponinae in Pará (Brazil); the data of ABSY and KerR (1977) and IWAMA and Melhem (1979) are obtained by microscopical analysis. We applied both these techniques : observations of flower visits and microscopical analysis. Though dealing with different plant and bee species, a general comparison can be made. Of the Papillionaceae, which are well represented in Surinam (AMSHOFF, 1939), only one species has been found in the pollen samples (Aeschynomene type) and only one flower visit has been observed (Trigona fulviventris guianae on Phaseolus lunatus). DucKe $(1901,1902)$ recorded 9 Melipona species visiting four different Papillionaceae. But the Palmae, Boraginaceae and Myrtaceae are missing on his list. Absence of palms may be caused by the fact that catching bees in palms is not very easy. The Boraginaceae and Myrtaceae on the other hand are shrubs and treelets with a cosmopolitic distribution and a distribution in the Tropics and Australia.

In both ABSY and KerR (1977) and IWAMA and Melhem (1979) the Euphorbiaceae are represented by more than one species. This is not surprising as most Euphorbiaceae are abundant pollen producers. Only one species, Melipona rufiventris paraensis, was caught while visiting an Euphorbiaceae, but no pollen of this family is found in the samples.

The Polygonaceae, in our case Polygonum acuminatum and Triplaris surinamensis, are not mentioned in any of the other four articles. 


\section{ACKNOWLEDGEMENTS}

We are indebted to Mr. K. van DeURSEN for his help. The Ministry of Agriculture, Husbandry and Fisheries in Surinam kindly offered their transport facilities. We would like to thank Dr. H. H. W. VeLthuis and Dr. W. PuNT for their valuable support during this research. This study was made possible by a grant from the Treub Maatschappij, Utrecht.

\section{RESUME}

\section{LES RESSOURCES EN NECTAR ET POLLEN POUR LES MÉLIPONES (MELIPONINAE, HYMENOPTERA)} AU SURINAM (AMÉRIQUE DU SUD)

Cette étude a trait aux ressources florales exploitées par les mélipones au Surinam. Les informations proviennent des notes jointes aux abeilles de la collection du Museum à Leiden, de l'analyse des échantillons de miel et de pollen pris dans les nids et des pelotes de pollen prélevées sur les abeilles butineuses et enfin des observations faites en champ.

Les connaissances sur ce sujet sont très peu nombreuses, bien qu'il existe de la bibliographie sur les ressources florales pour les mélipones d'Amérique du Sud hors du Surinam.

On a récolté des données pour 37 espèces sur 60 de mélipones connues au Surinam. Elles sont regroupées dans les tableaux I $a, b$ et $c$. Bien que ces données ne fournissent qu'une image fragmentaire, on peut conclure que les Caesalpiniaceae, les Clusiaceae, les Melastomataceae, les Palmae, Sesamum et Solanum sont des taxons importants pour ces abeilles, puisqu'ils sont visités par plusieurs espèces.

Si l'on compare les genres Melipona (Tabl. I $a$ ) et Trigona (s.s.) (Tabl. I $b$ ), on voit les différences suivantes : seules les espèces Melipona visitent les Podostemaceae et les Portulacaceae, tandis que les espèces Trigona ont seules été observées sur les Begoniaceae, Hyptis, les Loranthaceae, les Musaceae et les Rubiaceae.

Pour M.favosa, espèce pour laquelle on a obtenu de nombreux échantillons, les plantes butinées les plus importantes sont Avicennia germinans, Aciotes dichotoma, Syzygium cumini, Polygonum cuminatum et les espèces Solanum.

On rapporte ici pour la première fois l'existence de pollen récolté par les mélipones sur les Polygonaceae.

\section{ZUSAMMENFASSUNG}

NEKTAR- UND POLLENQUELLEN DER STACHELLOSEN BIENEN (MELIPONINAE, HYMENOPTERA) IN SURINAM (SÜD-AMERIKA)

In dieser Untersuchung werden Informationen über die Blütentracht gegeben, welche die Stachellosen Bienen in Surinam ausnutzen. Die Informationen wurden aus den Notizen gewonnen, die sich an den Bienen der Sammlung im Museum von Leiden befanden, ferner durch Analyse von Honig- und Pollenproben aus den Nestern und von Pollenhöschen an Sammelbienen sowie durch Feldbeobachtungen.

Obwohl es einige Publikationen über die Trachtquellen von Stachellosen Bienen Südamerikas ausserhalb von Surinam gibt, sind die Kenntnisse auf diesem Gebiet äusserst spärlich.

Es wurden Daten über 37 von den 60 Arten Stachelloser Bienen gewonnen, die in Surinam vorkommen. Sie sind in den Tabellen $\mathrm{I} a, b$ und $c$ zusammengestellt. Obwohl diese Daten nur ein fragmentarisches Bild vermitteln, kann man daraus doch den Schluss ziehen, dass die Caesalpiniaceae, Clusiaceae, Melastomataceae, Palmae, Sesamum und Solanum wichtige Gruppen für diese Bienen darstellen; sie werden jeweils von mehreren Bienenarten besucht. 
Beim Vergleich der Bienengattungen Melipona (Tab. Ia) und Trigona (s.s.; Tab. I $b$ ) erkennt man die folgenden Unterschiede: Nur die Melipona-Arten besuchen die Blüten der Podostemaceae und Portulacaceae, während für die Begoniaceae, Hyptis, Loranthaceae, Musaceae und Rubiaceae nur Trigona-Arten angeführt sind.

Für Melipona favosa, von welcher Art viele Proben untersucht wurden, sind Avicennia germinans, Aciotes dichotoma, Syzygium cumini, Polygonum acuminatum und Solanum-Arten die wichtigsten Trachtpflanzen.

Dass Stachellose Bienen Pollen von Polygonaceae sammeln, wird hier zum ersten Mal berichtet.

\section{LITERATURE}

ASBY M. L. and KeRR W. E., 1977. - Algumas plantas visitadas para obtençao de pōlen pelo operarias de Melipona seminigra merillae em Manaus. Acta Amazonica, 7 : 309-315.

Amshoff J., 1939. - The Papillionaceae. In : The flora of Suriname, vol. II (2), p. 1-257. A. Pulle, ed.

ANZENBERger G., 1977. - Ecological study of African carpenter bees of the genus Xylocopa (Hymenoptera, Anthophoridae). Z. Tierpsychol., $44: 337-374$.

BARrows E. M., 1976. - Nectar robbing and pollination of Lantana camara (Verbenaceae). Biotropi$c a, 8: 132-135$.

BuchmanN S. L., 1974. - Buzz pollination of Cassia quiedondilla (Leguminosae) by bees of the genera Centris and Melipona. Bull. South Calif. Acad. Sci., 73 : 171-173.

DuCKe A., 1901. - Beobachtungen über Blütenbesuch, Erscheinungszeit etc. der bei Parã vorkommenden Bienen. Z. Syst. Hymenopterol. Dipterol., 1 : 26, 28-32,49-51, 64-66.

Ducke A., 1902. - Beobachtungen über Blütenbesuch, Erscheinungszeit etc. der bei Pará vorkommenden Bienen. Allg. Z. Entomol., 7 : 322-326, 418-420.

Hubbell S. P. and Johnson L. K., 1978. - Comparative foraging behavior of six stingless bees exploiting a standardized resource. Ecology, $59: 1123-1136$.

IwAMA S. and MELhem T. S., 1979. - The pollen spectrum of the honey of Tetragonisca angustula angus- 1 tula Latreille (Apidae, Meliponinae). Apidologie, $10: 275-295$.

Johnson L. K. and Hubbell S. P., 1974. - Aggression and competition among stingless bees : field studies. Ecology, $55: 120-127$.

LindAuER M. and KerR W. E., 1958. - Die gegenseitige Verständigung bei den stachellosen Bienen. $Z$. vergl. Physiol., 41 : 405-434.

Rertsma T., 1969. - Size modifications of recent pollen under different treatments. Rev. Palaeobot. Palynol., 9 : 175-202.

REYNE A., 1962. - Angelloze bijen (Meliponinae) voorkomende in Suriname. Entomol. Ber., 22 : 30 37.

RouBIK D. W., 1978. - Competitive interactions between neotropical pollinators and africanized honeybees. Science, $201:$ 1030-1032.

SCHWARz H. F., 1948. - Stingless bees (Meliponidae) of the western hemisphere. Bull. amer. Mus. nat. Hist., 90 : $1-546$.

Note added in proof: the Partamona species 1 and 3 from Table 1c have been ascertained to be $P$. cupira (Smith) and P. musarum (Ckll) respectively. 